\title{
MiR-133b regulates bladder cancer cell proliferation and apoptosis by targeting Bcl-w and Akt1
}

Xiao-nan Chen, Ke-feng Wang, Zhen-qun Xu, Shi-jie Li, Qiang Liu, Dong-hui Fu, Xia Wang and Bin Wu*

\begin{abstract}
Background: MiR-133b is a muscle-specific microRNA; it has a role in the formation of cardiocytes and the expression of myocardium ion channels by regulating target genes. Many human malignant tumors demonstrate a low expression of miR-133b, as noted in colorectal, lung, esophagus and bladder cancers, but the role of miR-133b in bladder cancer is unknown.

Methods: The expression of miR-133b in clinical bladder cancer specimens and adjacent normal tissues was confirmed by stem-loop RT-PCR. We also analyzed the relationship between miR-133b expression and clinicopathological factors of bladder cancer. Bcl-w and Akt1 protein expression in 41 bladder cancer specimens and adjacent normal tissues was detected by Western blot. After transfection of miR-133b mimics or inhibitor into a T24 human bladder cancer cell line, BCl-w and Akt1 protein and mRNA expression were examined by Western blot and RT-PCR, respectively. The effect of miR-133b on T24 cell proliferation and apoptosis was measured by CCK-8 tests and flow cytometry, respectively.

Results: The expression of miR-133b in bladder cancer tissues from 41 patients was significantly down-regulated $(P<0.01)$; low expression of miR-133b was strongly associated with high-grade bladder cancer $(P<0.01)$. BCl-w and Akt1 proteins were significantly overexpressed in bladder cancer tissues versus adjacent normal tissues $(P<0.01$ for both). The expression of Akt1 and Bcl-w proteins and Akt1 mRNA, in T24 cells was significantly down-regulated or up-regulated after transfection of miR-133b mimics or inhibitor, respectively; however, there was no significant difference in Bcl-w mRNA expression. Transfection of HEK-293 T cells with miR-133b significantly suppressed a luciferase-reporter containing the Bcl-w or Akt 13 '-untranslated regions. MiR-133b mimics significantly inhibited T24 cell proliferation, as well as increased T24 cell apoptosis $(P<0.05$ and $P<0.01$, respectively) while the miR-133b inhibitor increased and decreased these, respectively $(P<0.05$ for both).
\end{abstract}

Conclusions: MiR-133b may play a very important role in the proliferation and apoptosis of T24 cells by regulating the expression of Bcl-w and Akt1.

Keywords: miR-133b, Bcl-w, Akt1, Bladder cancer, Proliferation, Apoptosis

\section{Introduction}

Bladder cancer is the most common malignant tumor of the urinary system among Chinese. Most tumors (95\%) originate from the urothelium, but the pathogenesis of bladder cancer has been unclear to date. While morbidity due to bladder cancer has been increasing on a yearly basis, the main treatment strategy has been surgery. However, the recurrence rate of bladder cancer is high,

\footnotetext{
* Correspondence: binwucmu@163.com

Department of Urology, Shengjing Hospital of China Medical University, Shenyang, Liaoning 11004, P.R. China
}

\section{() Biomed Central}

and advanced cases are usually complicated by local invasion and distal metastases, with poor outcomes. Understanding the molecular mechanisms of bladder cancer may contribute to innovative treatments.

MicroRNAs (miRNAs) are short (20-24-nt) single chain, non-coding RNAs that exist in eucaryons; their expression differs according to the specific tissue and developmental stage of individuals. They also have important regulatory functions during development and differentiation. By targeting 3' untranslated regions (3'UTRs) of cognate mRNAs,miRNAs are involved in the translation 
or direct degradation of mRNAs, and thus regulate gene expression [1,2]. Some researchers have shown that more than $50 \%$ of miRNA genes are located in regions related to tumors. In addition, different kinds of tumors express specific miRNAs, which may indicate that miRNAs have oncogene- or anti-oncogene-like functions and may play a role in the development of human tumors [3]. MiR-133b is a type of muscle-specific microRNA; it takes part in the formation of cardiocytes and the expression of myocardium ion channels by regulating target genes. Many human malignant tumors, such as colorectal,lung, esophagus and bladder cancer [4-7], express low levels of miR-133b; however, the role of miR-133b in bladder cancer is still unclear.

Bcl-w (also named BCL2L2) is a member of the Bcl-2 protein family and has a molecular weight of $22 \mathrm{kDa}$. The Bcl-2 gene family is made up of many members, including apoptosis inhibiting (e.g. Bcl-2, Bcl-xL, Bcl-w) and apoptosis promoting proteins (e.g. Bax, Bad) [8], which regulate programmed cell death. The proteins of this family form dimers that are involved in DNA damage or apoptosis in abnormal cells, such as tumor cells, by breaking the balance between apoptosis promoting and apoptosis inhibiting proteins [9]. Bcl-w shows higher expression in some epithelium-derived tumors, such as colorectal, cervical and breast [10-13]. However, reports in the literature relating to the expression and function of Bcl-w in bladder cancer are rare.

Akt1, a serine/threonine-protein kinase, also known as Akt kinase, is involved in the regulation of various downstream signaling pathways, such as those of cell metabolism, proliferation, survival, growth, and angiogenesis $[14,15]$. A past study indicated that the Akt1 kinase was most frequently activated during proliferation and survival pathways in cancer [16]. Kim et al. [17] reported that [6]-shogaol reduced the constitutive phosphorylation of signal transducer and activator of transcription 3 (STAT3) and decreased the expression of cyclin D1/3, which are target proteins in the Akt signaling pathway in non-small cell lung cancer. Gai et al. [18] reported that ursolic acid is important in inducing apoptosis, via the suppression of Akt/NF- $k B$ signaling in T24 human bladder cancer cells, and this occurs in a dose-dependent manner. Juanpere et al. [19] found that mutations in FGFR3 and PIK3CA, singly or combined with RAS and Akt1, were associated with Akt but not with MAPK pathway activation in urothelial bladder cancer. Previous reports have shown that Akt1 is involved in the regulation of bladder cancer; however, it is unclear whether miR133b can regulate the expression of Akt1 in T24 human bladder cancer cells.

According to past bioinformatics prediction results, we speculated that Bcl-w and Akt1 might be target genes for miR-133b. In this study, we detected the expression of miR-133b, Bcl-w and Akt1 in clinical bladder cancer tissues. The functional role of miR-133b in bladder cancer and its influence on Bcl-w and Akt1 protein and mRNA expression, and cell proliferation and apoptosis, was studied after transfection of miR-133b mimics or inhibitor into a transitional human bladder carcinoma cell line, T24.

\section{Results}

MiR-133b expression is downregulated in bladder cancer tissues

Expression levels of miR-133b were measured by stemloop RT-PCR in 41 bladder cancer specimens and their corresponding adjacent normal tissues. Quantitative analysis indicated that miR-133b expression was significantly decreased in bladder cancer specimens compared to adjacent normal tissues $(P<0.01$; Figure 1$)$. These results implied that down-regulation of miR-133b may be involved in human bladder cancer disease processes.

\section{A negative relationship between miR-133b expression and the pathological grading of bladder cancer}

Bladder cancer specimens were divided into low expression (below average expression of 30.4) or high expression groups (expression levels higher than the average of 30.4) according to the relative expression of miR-133b, normalized to U6 RNA. We found low miR-133b expression and high pathological grading were significantly negatively correlated $(P=0.003$; Table 1$)$. However, there was no significant association between miR-133b expression and gender, clinical stage or neoplasm recurrence (Table 1). These results suggested miR-133b downregulation in human bladder cancer is strongly linked to a high-grade pathology.

\section{Determination of miR-133b sense and antisense transfection efficiency}

The relative expression of miR-133b in cells transfected by miR-133b mimics (sense) and inhibitor (antisense) was determined by qRT-PCR. We found the expression of miR$133 \mathrm{~b}$ were significantly increased and decreased after transfection of miR-133b mimics $(P<0.01)$ and an miR-133b inhibitor $(P<0.01)$, respectively, into T24 cells (Figure 2$)$.

\section{Bcl-w and Akt1 are putative targets of miR-133b according to bioinformatics results}

To gain a greater understanding of the role of miR-133b in the pathogenesis of human bladder cancer, we looked for its potential downstream targets. Six bioinformatics algorithms were used to scan for possible targets and two identified: Bcl-w and Akt1. Bcl-w was predicted to be a target of miR-133b by five miRNA target prediction algorithms (Diana-microT, miRanda, miRWalk, PICTAR, TargetScan), and Akt1 was predicted to be a target of miR-133b by PITA. 


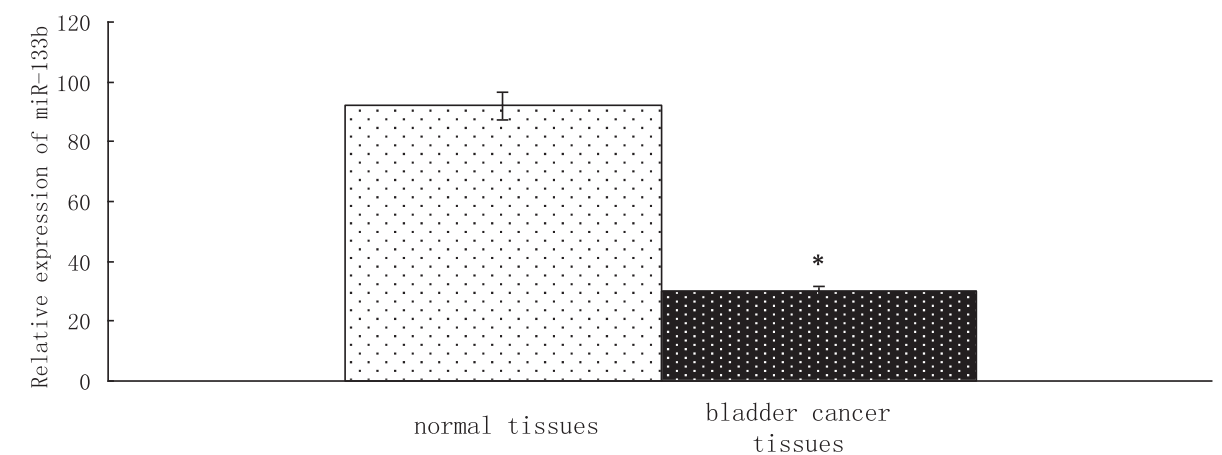

Figure 1 MiR-133b expression is downregulated in bladder cancer tissue. Expression levels of miR-133b were measured by stem-loop RT-PCR in bladder cancer specimens and corresponding, adjacent normal tissues. U6 RNA was used as an endogenous normalizer and the relative combined expression levels of miR-133b are shown. $2^{-\Delta \Delta C t}$ values $\pm S E M, n=41,{ }^{*} P<0.01$.

\section{Luciferase reporter assay results}

To verify the binding of miR-133b to the 3 '-UTR of Bcl-w and Akt1, a luciferase reporter assay was used. Results showed that miR-133b significantly decreased the luciferase activity of the Bcl-w (Figures $3 a$ and b) and Akt1 (Figures 3c and d) 3'-UTRs in HEK-293 T cells $(P<0.01$ for both), but not mutant sequences of the $3^{\prime}$-UTR of $\mathrm{Bcl}-\mathrm{w}$ and Akt1. These results indicated that miR-133b bound specifically to the $3^{\prime}$-UTR of Bcl-w and Akt1 as predicted.

\section{Upregulated Bcl-w and Akt1 protein expression in bladder cancer tissue}

Bcl-w and Akt1 protein expression was detected by Western blot in 41 bladder cancer specimens and adjacent normal tissues. We found that the combined expressions of Bcl-w (Figure 4) or Akt1 (Figure 5) proteins were significantly increased in bladder cancer specimens compared to

Table 1 The relationship between miR-133b expression and clinicopathological characterisics of bladder cancer

\begin{tabular}{|c|c|c|c|c|}
\hline \multirow[t]{2}{*}{ Charactistics } & \multirow[t]{2}{*}{$n=41$} & \multicolumn{2}{|c|}{ MiR-133b level } & \multirow{2}{*}{$\begin{array}{l}P \\
\text { value }\end{array}$} \\
\hline & & High (\%) & Low (\%) & \\
\hline \multicolumn{5}{|l|}{ Gender } \\
\hline Male & 29 & $11(64.5)$ & $18(75)$ & $0.475^{\mathrm{a}}$ \\
\hline Female & 12 & 6(35.3) & $6(25)$ & $0.187^{\mathrm{a}}$ \\
\hline \multicolumn{5}{|l|}{ Clinical stage } \\
\hline Ta-T1 (non-invasive) & 24 & 12 & 012 & \\
\hline T2-T4 (invasive) & 17 & 5 & 12 & $0.003^{b^{*}}$ \\
\hline \multicolumn{5}{|l|}{ Pathological grading } \\
\hline Low level & 19 & 13 & 6 & \\
\hline High level & 21 & 4 & 17 & \\
\hline \multicolumn{5}{|c|}{ Neoplasm recurrence } \\
\hline Early-onset & 25 & 10 & 15 & $0.812^{a}$ \\
\hline Recurrent & 16 & 7 & 9 & \\
\hline
\end{tabular}

${ }^{\mathrm{a} C h i-s q u a r e}$ test, ${ }^{\mathrm{b}}$ Sided Fisher's exact test, ${ }^{*} P<0.01$. adjacent normal tissues $(P<0.01$ for both). These results suggest roles for Bcl-w and Akt1 in the pathogenesis of human bladder cancer.

Effect of miR-133b on Bcl-w and Akt1 mRNA and protein expression in T24 human bladder cancer cells

The effects of miR-133b mimics or an inhibitor on levels of Bcl-w and Akt1 mRNA and protein in a human bladder cancer cell line, T24, were studied. Transfection of miR-133b-sense or miR-133b-antisense into T24 cells caused Akt1 mRNA expression to be significantly downregulated or up-regulated ( $P<0.05$ for both), respectively (Figures $6 \mathrm{~b}$ and $\mathrm{d}$ ); however, there was no significant difference in Bcl-w mRNA expression (Figures 6a and c). Transfection of miR-133-sense into T24 cells caused Bcl-w (Figures 6e and ) and Akt1 (Figures $6 \mathrm{~g}$ and $\mathrm{h}$ ) protein expression to be significantly down-regulated $(P<0.05$ for both; Figures $6 \mathrm{e}$ and $\mathrm{f}$ ). Transfection of miR-133b-antisense into T24 cells caused Bcl-w (Figures 6i and j) and Akt1 protein (Figures 6k and l) expression to be significantly up-regulated $(P<0.05$ for both). These results indicate that miR-133b down-regulates Akt1 mRNA and protein, and $\mathrm{Bcl}-\mathrm{w}$ protein, but not its mRNA.

\section{MiR-133b inhibits cell proliferation of T24 cells}

The effect of miR-133b on T24 cell proliferation was studied. Cell proliferation assays were performed at $12 \mathrm{~h}$, $24 \mathrm{~h}, 48 \mathrm{~h}$ and $72 \mathrm{~h}$ after miR-133b-sense or miR-133bantisense transfection of T24 cells. The cell proliferation of untreated or miR-133b-sense-NC transfected T24 cells was significantly greater compared to miR-133b-sense transfected cells $(P<0.05$; Figure $7 \mathrm{~A})$. The cell proliferation of untreated or miR-133b- antisense -NC transfected T24 cells was significantly less compared to miR-133bantisense transfected cells $(P<0.05$; Figure $7 \mathrm{~B})$. These results indicate that miR-133b expression in T24 cells inhibits their proliferation. 


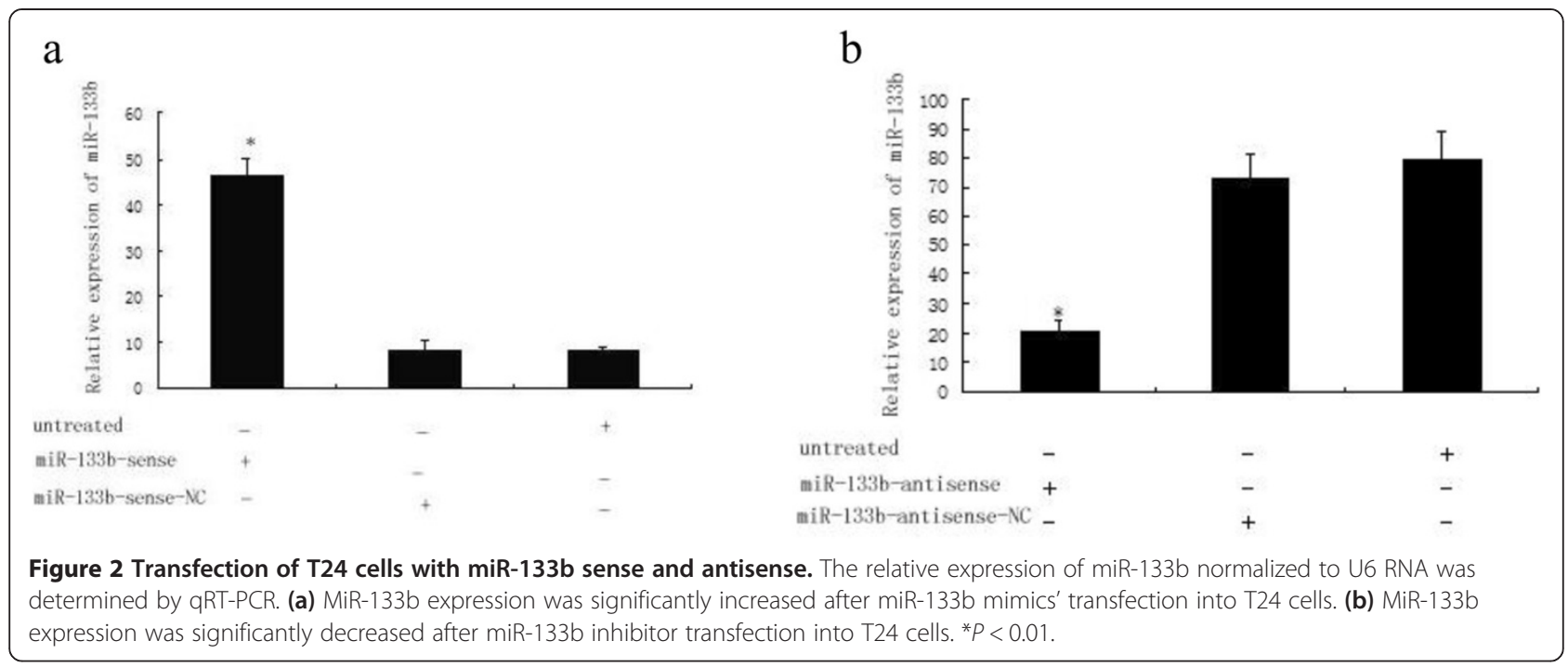

\section{MiR-133b promotes apoptosis of T24 cells}

In this study, Annexin V-FITC double staining flow cytometric analysis was performed to evaluate the effect of miR-133b on apoptosis in T24 cells. Apoptosis was determined $24 \mathrm{~h}$ after transfection. Compared with
miR-133b-sense transfected cells (16.47\%), the apoptosis rate of untreated cells (1.95\%) was significantly less $(P<0.01$; Figure 8a). Compared with miR-133bantisense transfected cells $(1.25 \%)$, the apoptosis rate of untreated cells $(2.14 \%)$ was significantly greater $(P<0.05$;

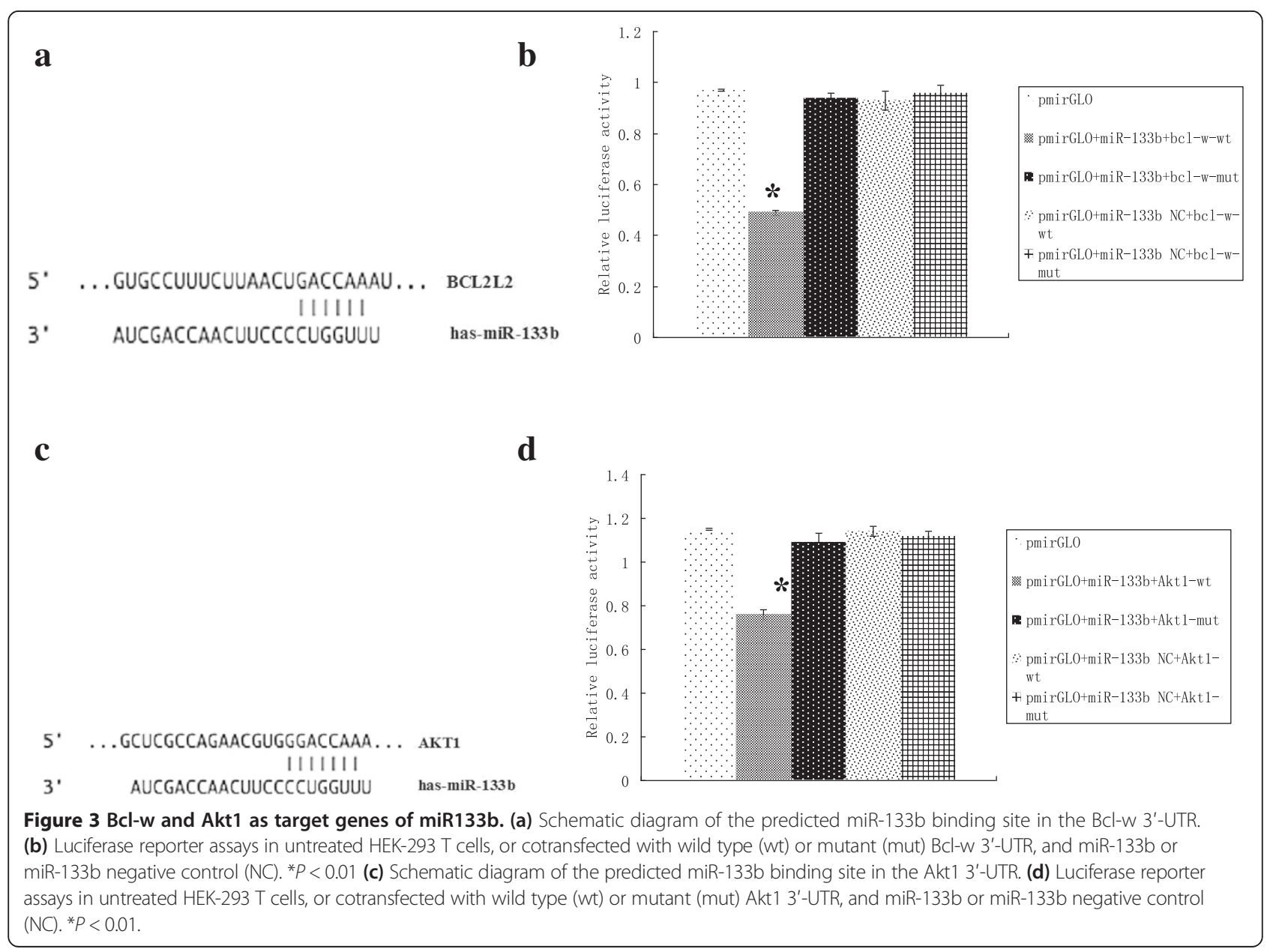



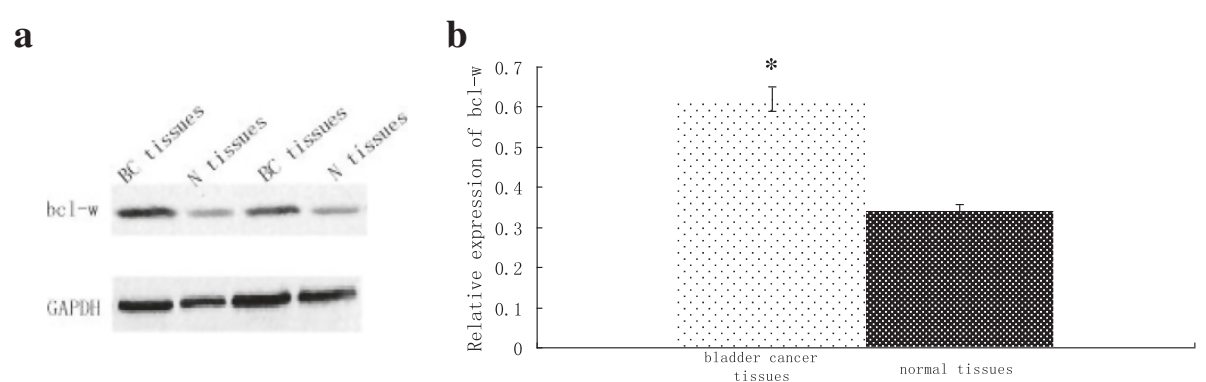

Figure $4 \mathrm{Bcl}-\mathrm{w}$ expression is upregulated in bladder cancer tissue. (a) $\mathrm{BCl}-\mathrm{w}$ protein expression was determined by Western blot in bladder cancer (BC) and normal (N) tissues. (b) Optical density values for combined Bcl-w protein relative to GAPDH in bladder cancer (BC) and normal (N) tissues. $n=41 .{ }^{*} P<0.01$.

Figure $8 \mathrm{~b})$. This data indicates that miR-133b promotes apoptosis in T24 cells.

\section{Discussion}

The development of epigenetics, accounting for $99 \%$ of the human genome's non-coding sequences, has attracted considerable attention by scientists, with miRNA research becoming a significant hotspot in recent years [20-22]. As non-coding, small molecule RNAs, miRNAs are involved in many important physiological and pathological processes, such as cell proliferation, development, differentiation, virus infection and tumorigenesis, and are widely dysregulated in various cancers [23-26]. MiRNA exerts its functions in a manner similar to oncogenes or tumor suppressor genes: tumor development and progression occur by the regulation of target genes. MiRNA-induced oncogene functions are often highly expressed in tumors, and miRNA-induced tumor suppressor genes often show low or no expression [27-29]. An miRNA can regulate multiple target genes, and a target gene can also be regulated by a number of miRNAs; both miRNA and target gene form a complex regulatory network, which plays an important role in the occurrence and development of human tumors.
Recent studies have shown that the expression of miR$133 \mathrm{~b}$ is abnormal in many tumors. Masayuki et al. [30] found that the expression of miR-133b was significantly lower in esophageal squamous cell carcinoma; the proliferation and invasion of a carcinoma cell line could be inhibited after miR-133b transfection. In addition, they also found that miR-133b could affect the biological behavior of the tumor through regulating gene expression of FSCN1. Chiyomaru et al. [31] reported that miR-145 and miR-133a could influence the biological behavior of bladder cancer cells by also regulating the expression of FSCN1. We therefore speculated that miR-133b, whose nucleotide sequences are similar to those of miR-133a, may also play an important regulatory role in bladder cancer. Hu et al. [32] found that the expression of miR$133 \mathrm{~b}$ was significantly decreased in colorectal cancer and in colorectal cancer cell lines SW-620 and HT-29; furthermore, it was found that miR-133b played an important role in vivo and in vitro by regulating the tyrosine kinase receptor, c-Met.

In this study, we examined expression levels of miR-133b in bladder cancer tissues from 41 patients by RT-PCR and found miR-133b was significantly down-regulated in $\mathbf{a}$

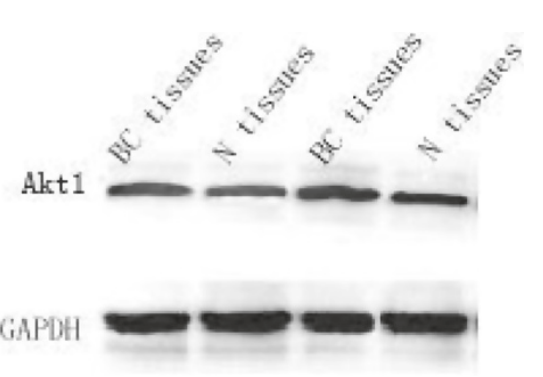

b

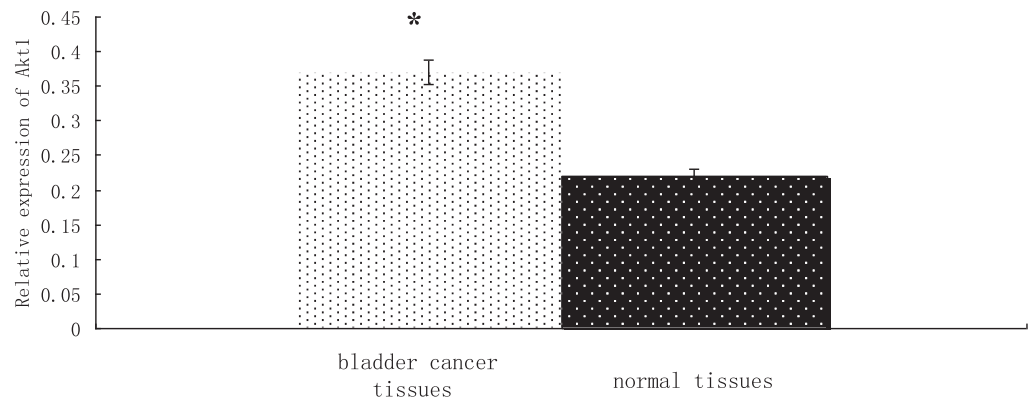

Figure 5 Akt1 protein expression is upregulated in bladder cancer tissue. (a) Akt1 protein expression was determined by Western blot in bladder cancer (BC) and normal (N) tissues. (b) Optical density values for combined Akt1 protein relative to GAPDH in bladder cancer (BC) and normal $(\mathrm{N})$ tissues. $\mathrm{n}=41 .{ }^{*} \mathrm{P}<0.01$. 


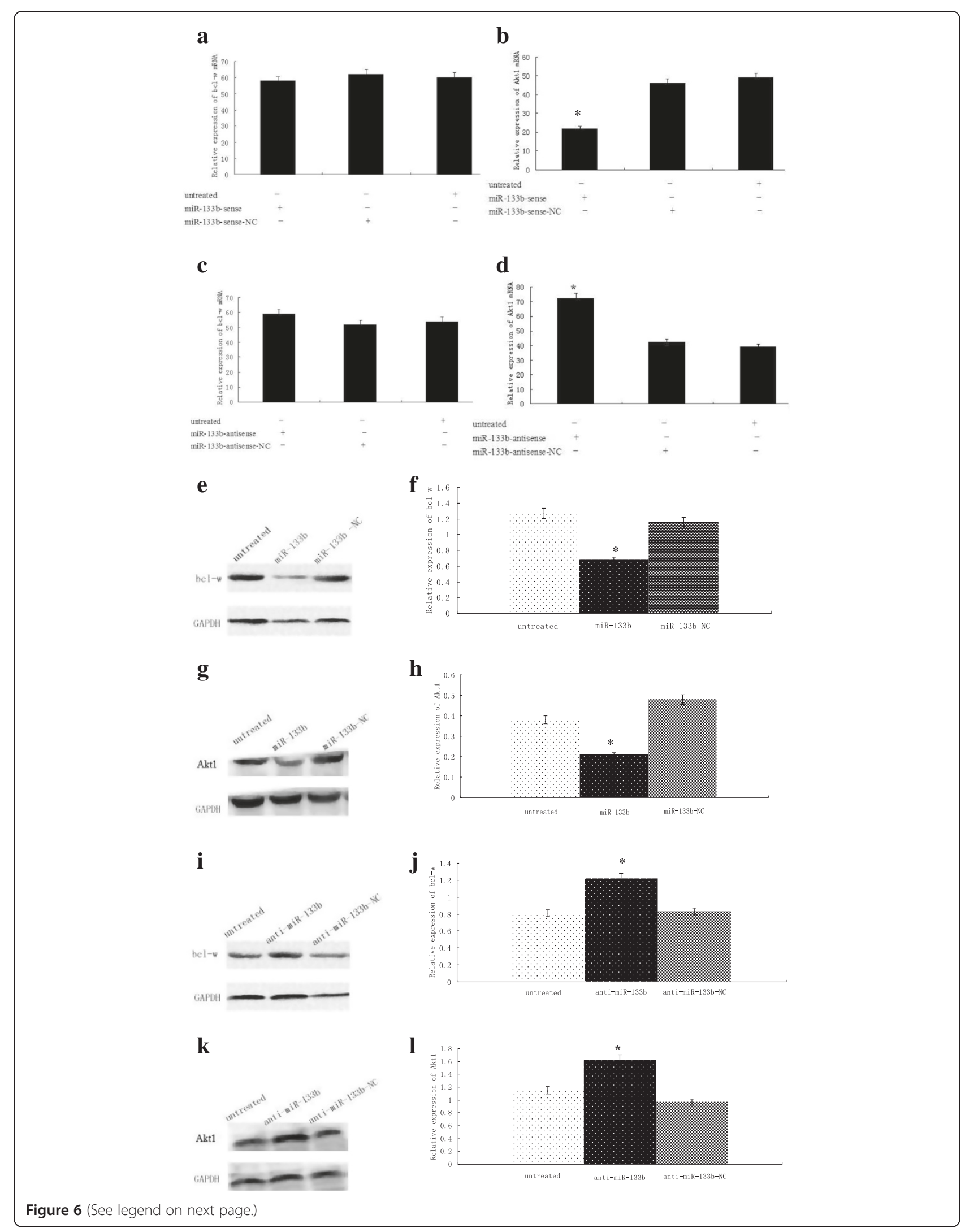


bladder cancer tissues, which was consistent with previous research. Our results suggested miR-133b might regulate certain oncogenes to inhibit tumorigenesis. We further analyzed the relationship between the expression of miR-133b and clinicopathological factors, and found that a lower expression level of miR-133b was strongly associated with high-grade bladder cancer. However, miR-133b and gender, clinical stage and neoplasm recurrence showed no significant correlation. These findings support the idea that miR-133b may be an important regulator in bladder cancer.

In our study, CCK-8 tests and flow cytometry were used to evaluate the effects of miR-133b on cell proliferation and apoptosis of T24 cells, respectively. We found that miR-133b overexpression caused T24 cell growth inhibition and apoptotic enhancement. Thus, we hypothesized that miR-133b may function as a tumor suppressor, and the abnormal expression of miR-133b might be an important factor in bladder cancer incidence.

As a member of the BCL2 family, Bcl-w is able to inhibit cell apoptosis. Recently, Bcl-w was found to be highly expressed in some epithelial tumors. Lee et al. reported that Bcl-w could inhibit tumor cell apoptosis by blocking the SAPK/JNK pathway in gastric adenocarcinoma [33]. Bae et al. found that Bcl-w promotes gastric cancer cell invasion by inducing matrix metalloproteinase- 2 expression via phosphoinositide 3-kinase (PI3 kinase), Akt, and Sp1 [34]. Guo et al. [35] reported that Bcl-w was observed in most human colon adenocarcinoma compared to normal tissues, which suggested that Bcl-w was involved in the regulation of colorectal cancer. The PI3 kinase-Akt pathway is frequently activated in cancer. Recent reports have identified that abnormal methylation of the Akt1 gene may be an early event during urocystic tumorigenesis and this should be further evaluated as a tumorigenesis marker for early detection of bladder cancer [36]. Askham et al. [37] reported the occurrence of an Akt1 mutation in bladder tumors. The Akt1 G49A (E17K) mutation was found in $2 / 44(4.8 \%)$ of bladder cancer cell lines and 5/184 $(2.7 \%)$ of bladder tumors. Cell lines expressing mutant Akt1 show constitutive Akt1 activation under conditions of growth factor withdrawal. In our study, the expression of Bcl-w and Akt1 proteins in 41 bladder cancer specimens and adjacent normal tissues was detected by Western blot assay. We found that Bcl-w and Akt1 proteins were significantly overexpressed in bladder cancer tissues versus adjacent normal tissues. This result is in accordance with previous research.

Melissa et al. reported that MiR-133b down-regulated the expression of MCL-1 and Bcl-w in lung adenocarcinoma cells, and overexpression of miR-133b increased the sensitivity of lung adenocarcinoma cells to gemcitabine [38]. We found the expression of Akt1 protein and mRNA in T24 cells was down-regulated and up-regulated, respectively, after transfection of miR-133b mimics or inhibitor. The expression of Bcl-w protein in T24 cells was down-regulated and up-regulated after transfection of miR-133b mimics or inhibitor, respectively, but there was no significant difference in Bcl-w mRNA expression.

In conclusion, in this paper we show that miR-133b expression is downregulated in bladder cancer tissues and is linked to high-grade bladder cancer. We show that miR-133b inhibits cell proliferation and induces apoptosis in a human bladder cancer cell line, T24. We found Bcl-w and Akt1 to be putative targets of miR133b and show increased expression of these proteins in a

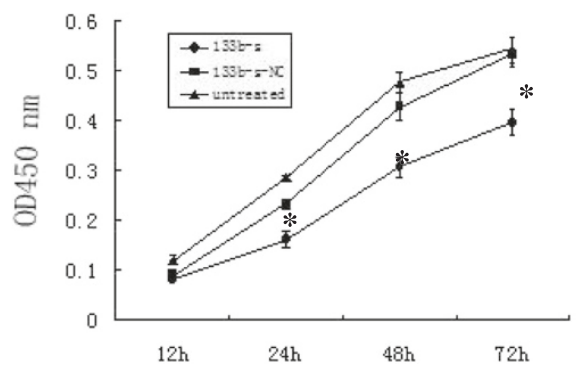

b

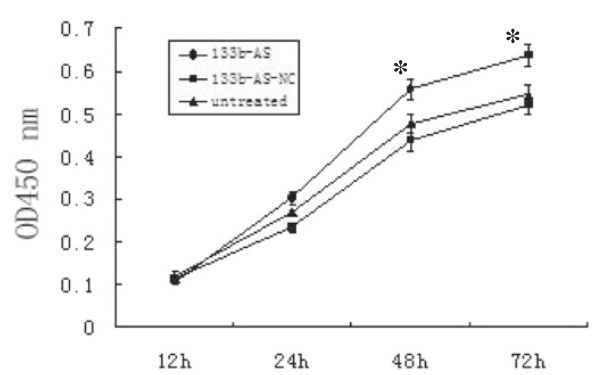

Figure 7 Effect of miR-133b on proliferation of T24 cells. (a) T24 cells were untreated or transfected with miR-133b-sense- negative control (NC) or miR-133b sense (S) for up to $72 \mathrm{~h}$. (b) T24 cells were untreated or transfected with miR-133b-antisense-negative control (NC) or miR-133b antisense (AS) for up to $72 \mathrm{~h}$. Cell proliferation was measured by CCK-8. ${ }^{*} P<0.05$. 


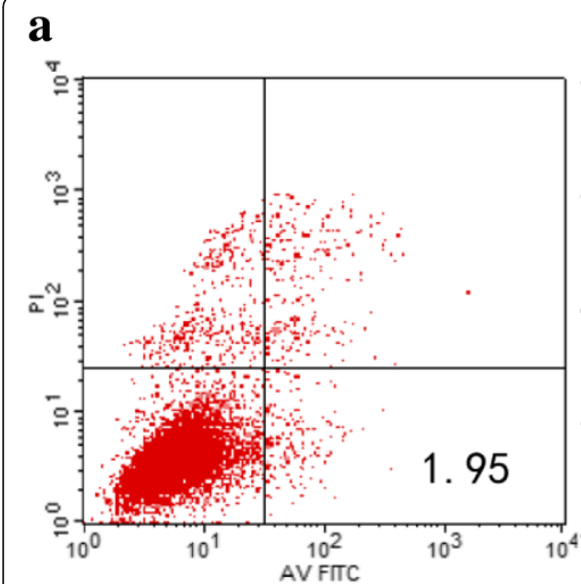

(a)

b

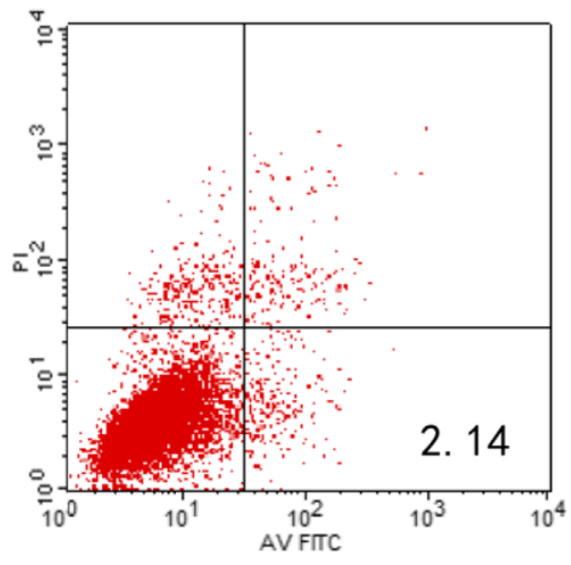

(a)

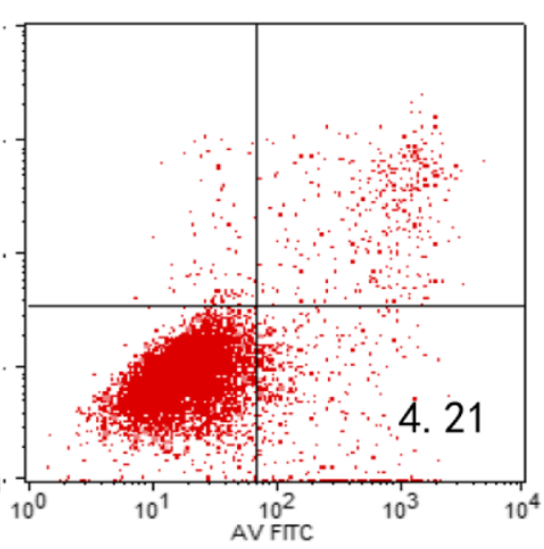

(b)

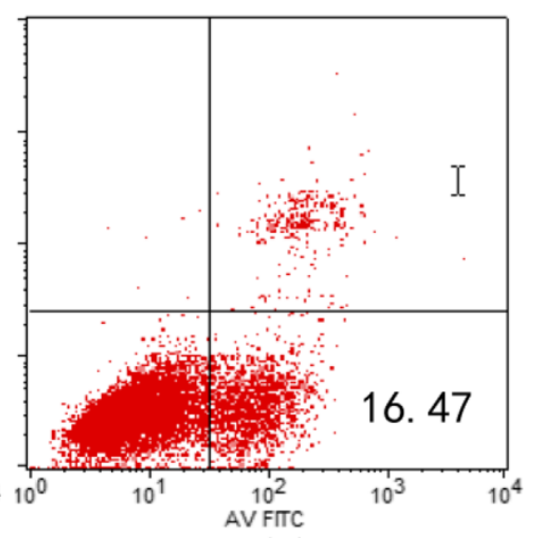

(c)

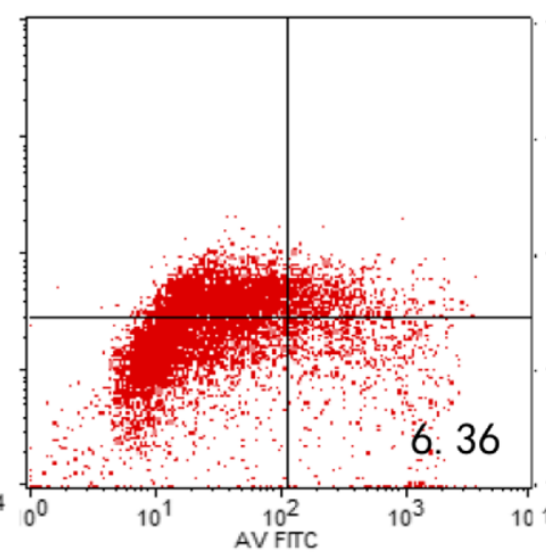

(b)

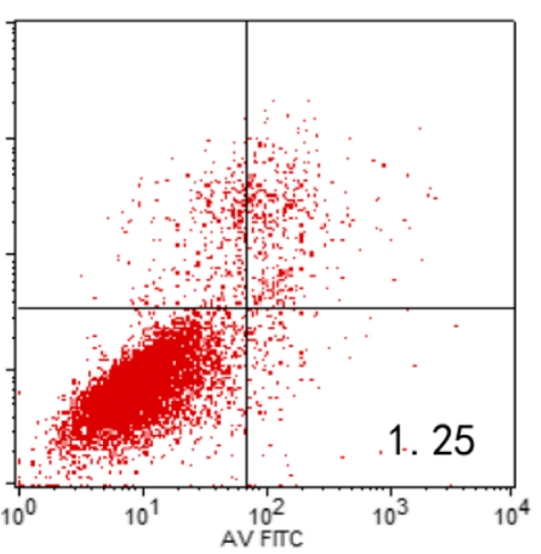

(c)

Figure 8 The effect of miR-133b on T24 cell apoptosis. (a) The effects of miR-133b-sense transfection on apoptosis of T24 cells: (a) untreated group, (b) miR-133b-sense-negative control (NC) group and (c) miR-133b-sense group. (b) The effects of miR-133b-antisense transfections on apoptosis of T24 cells: (a) untreated group, (b) miR-133b-antisense-normal control (NC) group and (c) miR-133b-antisense group. Apoptosis was measured by flow cytometric analysis of T24 cells stained with Annexin V-FITC $24 \mathrm{~h}$ after transfection.

bladder cancer tissues. We show mi-R133b regulated Bcl-w and Akt1 in cultured T24 cells and we therefore speculated that miR-133b affects the biological behavior of bladder cancer by regulating the expression of Bcl-w and Akt1. However, mi-R133b's specific role in bladder cancer and the mechanism(s) involved is unclear and requires further study.

\section{Materials and methods}

\section{Specimens}

Forty-one specimens of urothelial bladder cancer and adjacent normal tissue (more than $5 \mathrm{~cm}$ away from the tumor) were obtained from the Department of Urology, Shengjing Hospital of China Medical University, between December 2008 and December 2010. This study was approved by our institution's Research Ethics Committee; informed consent was obtained from each patient. The age of patients ranged from 43 to 87 years, mean $62.3 \pm 6.7$ years, and included 29 males and 12 females. The histological grade and clinical stage were determined according to World Health Organization WHO (2004) pathological grading standards and the International Union Against Cancer UICC (2002) TNM clinical staging system.

\section{Cell culture and transfection}

The human bladder cancer cell line T24 was obtained from the typical cell culture collection Committee of the Chinese Academy of Sciences Library (Shanghai, China). The cells were cultured in RPMI-1640 medium (HyClone, 
Logan, UT, USA) supplemented with $10 \%$ heat-inactivated FBS (JRH Biosciences, Lenexa, KS, USA), $100 \mathrm{U} / \mathrm{ml}$ penicillin, and $100 \mathrm{mg} / \mathrm{L}$ streptomycin. Cultures were maintained in a humidified atmosphere of $5 \% \mathrm{CO}_{2}$ at $37^{\circ} \mathrm{C}$. The following oligonucleotides were purchased from GenePharma (Shanghai, China): double-stranded miR133b sense (mimics) and miR-133b-sense-negative control (NC); miR-133b -antisense (inhibitor) and miR-133bantisense-negative control (NC); and sequences are as follows: miR-133b, 5' - UUUGGUCCCCUUCAACCAG CUA-3', 5'-GCUGGUUGAAGGGGACCAAAUU-3' and its NC 5'-UUCUCCGAACGUGUCACGUTT-3', 5' - AC GUGACACGUUCGGAGAATT-3'; miR-133b-antisense, 5'-UAGCUGGUUGAAGGGGACCAAA-3' and its NC 5'-CAGUACUUUUGUGUAGUACAA-3'. The day before transfection, cells were seeded in antibiotic-free medium. MiR-133b-sense, miR-133b-sense-NC, miR-133b-antisense and miR-133b-antisense-NC transfections were carried out using Lipofectamine 2000 in accordance with the manufacturer's guidelines (Invitrogen). Untreated cells were designated as the control group.

\section{miR-133b target gene prediction}

Computer-based programs were used to predict potential miR-133 targets. Using "has-miR-133b" as a search term, we queried PicTar (http://pictar.mdc-berlin.de/), TargetScan (http://www.targetscan.org/), miRWalk (http:// www.umm.uni-heidelberg.de/apps/zmf/mirwalk/) miRanda (http://www.microrna.org/microrna/home.do), DIANAmicroT (http://diana.cslab.ece.ntua.gr/microT/) and PITA (http://genie.weizmann.ac.il/pubs/mir07/mir07_data.html).

\section{Luciferase reporter assay}

The target sequences of Bcl-w and Akt1 wild type 3' UTR were cloned into a luciferase vector which contained the Renilla luciferase gene. In addition, mutant 3' UTR was also cloned. HEK-293Tcells were cotransfected with miR-NC or miR-133b mimics using Lipofectamine 2000 (Invitrogen). Cells were collected $48 \mathrm{~h}$ after transfection and analyzed using the Dual-Luciferase Reporter Assay System (Promega, Madison, WI), and luciferase activity values were normalized relative to that of the Renilla luciferase internal control.

\section{Quantitative Real Time (RT)-PCR (qRT-PCR)}

MiRNA of 41 bladder cancer specimens paired to adjacent normal bladder tissues were extracted using the mirVana miRNA Isolation Kit (Ambion, United States) according to the manufacturer's instructions. Expression levels of miR-133b were analyzed by using stem-loop RT-PCR. MiR-133b stem-loop primer and U6 primer were purchased from Beijing Microread Gene Technology (Beijing, China). PrimeScript ${ }^{\circ} \mathrm{RT}$ reagent Kit and SYBR $^{\circ}$ Premix Ex $\mathrm{Taq}^{\mathrm{Tm}}$ were purchased from TaKaRa
(Otsu, Japan). U6 RNA was used as an internal control to normalize the relative abundance of miR-133b. The expression levels of $\mathrm{Bcl}-\mathrm{w}$ and Akt1 mRNA were measured in T24 cells transfected with miR-133b-sense, miR-133bsense-NC, miR-133b-antisense and miR-133b-antisenseNC. RT-PCR was performed using the following primers: miR-133b, 5'-GCGCTTTGGTCCCCTTC -3'/5'-CAGT GCAGGGTCCGAGGT-3'; U6, 5'-CTCGCTTCGGCAGCACA-3'/5'-AACGCTTCACGAATTTGCGT-3'; Akt1, 5' - GGTGATCCTGGTGAAGGAGA-3'/5' - CTTAATG TGCCCGTCCTTGT-3' [39]; and Bcl-w, 5'CACCCA GGT CTCCGATGAAC3'/5'TTGTTGACACTCTCA GC ACAC3' [40]. PCR cycles were as follows: $37^{\circ} \mathrm{C}$ for $15 \mathrm{~min}$, $85^{\circ} \mathrm{C}$ for $5 \mathrm{~s}$ for reverse transcription, followed by 40 cycles of $95^{\circ} \mathrm{C}$ for $10 \mathrm{~s}, 95^{\circ} \mathrm{C}$ for $5 \mathrm{~s}, 61^{\circ} \mathrm{C}$ for $20 \mathrm{~s}$. Cycle threshold $(\mathrm{Ct})$ values were collected at the end of each PCR. Each sample was tested in triplicate, and the relative quantification equation $\left(\mathrm{RQ}=2^{-\Delta \Delta C \mathrm{~T}}\right.$ ) was used to calculate the relative expression.

\section{Western blot analysis}

Western blot analysis of Bcl-w and Akt1 proteins was conducted in 41 bladder cancer specimens paired to adjacent normal tissues, and also in a T24 cell line. Tissue and cell protein concentrations were determined using the Enhanced BCA Protein Assay Kit (Beyotime, Shanghai, China); equal amounts of proteins $(20-30 \mu \mathrm{g})$ were separated by $15 \%$ SDS-polyacrylamide gel (SDS-PAGE) and transferred to PVDF membranes. After incubation with specific primary antibodies overnight at $4{ }^{\circ} \mathrm{C}$, membranes were further incubated for 1 hour with horseradish peroxidase-conjugated secondary antibodies. Integrated density values were analyzed using Fluor Chen 2.0 software (Olympus, Yokohama, Japan) and normalized to those of glyceraldehyde-3-phosphate dehydrogenase (GAPDH).

\section{Cell counting kit-8}

Cell proliferation analysis was performed using the Cell Counting Kit-8 (CCK-8) (Tongren, Shanghai, China). The optimum reaction time of CCK- 8 was determined to be $2.5 \mathrm{~h}$. When $80 \%$ confluent, T24 cells $(100 \mu \mathrm{L} /$ well $)$ were seeded into 96-well plates, and were left untransfected or transfected with miR-133b-sense or miR-133bantisense, and further incubated for 12, 24, 48, and 72 hours using three replicates. Approximately $10 \mu \mathrm{L}$ of tetrazolium salt, WST-8, was added to each well for 1 hour. The optical density (OD), at $450 \mathrm{~nm}$, of each well was determined by microplate reader.

\section{Flow cytometric analysis}

Apoptosis analysis was performed using a BioVision Annexin V-FITC reagent kit (Sigma-Aldrich; St. Louis, MO, USA) and flow cytometry. T24 cells were seeded 
onto 6-well plates and transfected with miR-133b-sense or miR-133b-antisense at $80 \%$ confluency. After transfection, cells were trypsinised and washed twice with PBS $(2000 \mathrm{rpm} / \mathrm{min}, 5 \mathrm{~min})$. Cells $\left(1-5 \times 10^{5}\right)$ were collected, then $500 \mu \mathrm{L}$ binding buffer, $5 \mu \mathrm{L}$ Annexin VFITC and $5 \mu \mathrm{L}$ propidium iodide were added. Cells were incubated for 5-15 min after mixing, and flow cytometry carried out within an hour.

\section{Statistical analysis}

Statistical analysis of data was performed using SPSS19.0 software. Statistical evaluation was performed using oneway analysis of variance (ANOVA; $P<0.05$ ) and Student's t-test. All data from experiments were expressed as mean \pm SD unless otherwise stated.

\section{Abbreviations \\ miRNA: microRNA; miR133b: microRNA -133b; UTRs: Untranslated regions; NC: Negative control; CCK-8: Cell counting kit-8; OD: Optical density.}

\section{Competing interests}

The authors declare that they have no competing interests.

\section{Authors' contributions}

$\mathrm{XC}$ and BW were involved in the concept and in the design, analysis and interpretation of the data and drafting of the manuscript. XC performed all the experiments and acquired the data. KW and ZX both participated in Western blotting assays and RT-PCR. SL and QL performed miR-133b target gene predictions, cell culture, transfections and dual luciferase reporter assays. DF and XW conducted cell counts with CCK-8, flow cytometric analysis and statistical analysis. All authors read and approved the final manuscript.

\section{Acknowledgments}

This study was financially supported (project F13-316-1-02) through the Shenyang Science and Technology Program. We give special thanks to all the teachers at the Department of Urology of Shengjing Hospital for their help and support.

Received: 28 December 2013 Accepted: 10 July 2014

Published: 19 July 2014

\section{References}

1. Wu L, Fan J, Belasco JG: MicroRNAs direct rapid deadenylation of mRNA. Proc Natl Acad Sci U S A 2006, 103(11):4034-4039.

2. Schickel R, Boyerinas B, Park SM, Peter ME: MicroRNAs: key players in the immune system, differentiation, tumorigenesis and cell death. Oncogene 2008, 27(45):5959-5974.

3. Zhang B, Pan X, Cobb GP, Anderson TA: MicroRNAs as oncogenes and tumor suppressors. Dev Biol 2007, 302(1):1-12.

4. Song T, Xia W, Shao N, Zhang X, Wang C, Wu Y, Dong J, Cai W, Li H: Differential miRNA expression profiles in bladder urothelial carcinomas. Asian Pac J Cancer Prev 2010, 11(4):905-911.

5. Catto JW, Miah S, Owen HC, Bryant H, Myers K, Dudziec E, Larré S, Milo M, Rehman I, Rosario DJ, Di Martino E, Knowles MA, Meuth M, Harris AL, Hamdy FC: Distinct MicroRNA alterations characterize high- and low-grade bladder cancer. Cancer Res 2009, 69(21):8472-8481.

6. Gottardo F, Liu CG, Ferracin M, Calin GA, Fassan M, Bassi P, Sevignani C, Byrne D, Negrini M, Pagano F, Gomella LG, Croce CM, Baffa R: Micro-RNA profiling in kidney and bladder cancers. Urol Oncol 2007, 25(5):387-392.

7. Bandrés E, Cubedo E, Agirre X, Malumbres R, Zárate R, Ramirez N, Abajo A, Navarro A, Moreno I, Monzó M, García-Foncillas J: Identification by Realtime PCR of 13 mature microRNAs differentially expressed in colorectal cancer and non-tumoral tissues. Mol Cancer 2006, 5:29.

8. Goldsmith KC, Lestini BJ, Gross M, Ip L, Bhumbla A, Zhang X, Zhao H, Liu X, Hogarty MD: $\mathrm{BH} 3$ response profiles from neuroblastoma mitochondria predict activity of small molecule Bcl-2 family antagonists. Cell Death Differ 2010, 17(5):872-882.
9. Vogler M, Dinsdale D, Dyer MJ, Cohen GM: Bcl-2 inhibitors: small molecules with a big impact on cancer therapy. Cell Death Differ 2009, 16(3):360-367

10. O'Reilly LA, Print C, Hausmann G, Moriishi K, Cory S, Huang DC, Strasser A: Tissue expression and subcellular localization of the pro-survival molecule Bcl-w. Cell Death Differ 2001, 8(5):486-494.

11. Pritchard DM, Print C, O'Reilly L, Adams JM, Potten CS, Hickman JA: Bcl-w is an important determinant of damage-induced apoptosis in epithelia of small and large intestine. Oncogene 2000, 19(34):3955-3959.

12. Adams JM, Cory S: The Bcl-2 apoptotic switch in cancer development and therapy. Oncogene 2007, 26(9):1324-1337.

13. Courchesne SL, Karch C, Pazyra-Murphy MF, Segal RA: Sensory neuropathy due to loss of Bcl-w. J Neurosci 2011, 31(5):1624-1634.

14. Kumar A, Rajendran V, Sethumadhavan R, Purohit R: AKT kinase pathway: a leading target in cancer research. ScientificWorldJournal 2013, 2013:756134.

15. Hennessy BT, Smith DL, Ram PT, Lu Y, Mills GB: Exploiting the PI3K/AKT pathway for cancer drug discovery. Nat Rev Drug Discov 2005, 4(12):988-1004.

16. Kumar A, Purohit R: Cancer associated E17K mutation causes rapid conformational drift in AKT1 Pleckstrin Homology (PH) domain. PLoS One 2013, 8(5):e64364.

17. Kim MO, Lee MH, Oi N, Kim SH, Bae KB, Huang Z, Kim DJ, Reddy K, Lee SY, Park SJ, Kim JY, Xie H, Kundu JK, Ryoo ZY, Bode AM, Surh YJ, Dong Z: [6]-Shogaol inhibits growth and induces apoptosis of non-small cell lung cancer cells by directly regulating Akt1/2. Carcinogenesis 2013 . Epub ahead of print.

18. Gai L, Cai N, Wang L, Xu X, Kong X: Ursolic acid induces apoptosis via Akt/ NF-KB signaling suppression in T24 human bladder cancer cells. Mol Med Rep 2013, 7(5):1673-1677.

19. Juanpere N, Agell L, Lorenzo M, De Muga S, López-Vilaró L, Murillo R, Mojal S, Serrano S, Lorente JA, Lloreta J, Hernández S: Mutations in FGFR3 and PIK3CA, singly or combined with RAS and AKT1, are associated with AKT but not with MAPK pathway activation in urothelial bladder cancer. Hum Pathol 2012, 43(10):1573-1582.

20. Lin PY, Yang PC: Circulating miRNA signature for early diagnosis of lung cancer. EMBO Mol Med 2011, 3(8):436-437.

21. Parasramka MA, Ho E, Williams DE, Dashwood RH: MicroRNAs, diet, and cancer: new mechanistic insights on the epigenetic actions of phytochemicals. Mol Carcinog 2012, 51(3):213-230.

22. Hummel R, Maurer J, Haier J: MicroRNAs in brain tumors: a new diagnostic and therapeutic perspective? Mol Neurobiol 2011, 44(3):223-234.

23. Bartel DP: MicroRNAs: genomics, biogenesis, mechanism, and function. Cell 2004, 116(2):281-297.

24. Esquela-Kerscher A, Slack FJ: Oncomirs - microRNAs with a role in cancer. Nat Rev Cancer 2006, 6(4):259-269.

25. Ambros V: MicroRNA pathways in flies and worms: growth, death, fat, stress, and timing. Cell 2003, 113(6):673-676.

26. Carlsson J, Davidsson S, Helenius G, Karlsson M, Lubovac Z, Andrén O, Olsson B, Klinga-Levan K: A miRNA expression signature that separates between normal and malignant prostate tissues. Cancer Cell Int 2011, 11(1):14.

27. Neely LA, Rieger-Christ KM, Neto BS, Eroshkin A, Garver J, Patel S, Phung NA, McLaughlin S, Libertino JA, Whitney D, Summerhayes IC: A microRNA expression ratio defining the invasive phenotype in bladder tumors. Urol Oncol 2010, 28(1):39-48.

28. Baffa R, Fassan M, Volinia S, O'Hara B, Liu CG, Palazzo JP, Gardiman M, Rugge M, Gomella LG, Croce CM, Rosenberg A: MicroRNA expression profiling of human metastatic cancers identifies cancer gene targets. J Pathol 2009, 219(2):214-221.

29. Veerla S, Lindgren D, Kvist A, Frigyesi A, Staaf J, Persson H, Liedberg F, Chebil G, Gudjonsson S, Borg A, Månsson W, Rovira C, Höglund M: MiRNA expression in urothelial carcinomas: important roles of miR-10a, miR-222, miR-125b, miR-7 and miR-452 for tumor stage and metastasis, and frequent homozygous losses of miR-31. Int J Cancer 2009, 124(9):2236-2242.

30. Kano M, Seki N, Kikkawa N, Fujimura L, Hoshino I, Akutsu Y, Chiyomaru T, Enokida H, Nakagawa M, Matsubara H: MiR-145, miR-133a and miR-133b: tumor-suppr-Essive miRNAs target FSCN1 in esophageal squamous cell carcinoma. Int J Cancer 2010, 127(12):2804-2814.

31. Chiyomaru T, Enokida H, Tatarano S, Kawahara K, Uchida Y, Nishiyama K, Fujimura L, Kikkawa N, Seki N, Nakagawa M: MiR-145 and mrR-133a function as tumor suppressors and directly regulate FSCN1 expression in bladder cancer. Br J Cancer 2010, 102(5):883-891. 
32. Hu G, Chen D, Li X, Yang K, Wang H, Wu W: miR-133b regulates the MET proto-oncogene and inhibits the growth of colorectal cancer cells in vitro and in vivo. Cancer Biol Ther 2010, 10(2):190-197.

33. Lee HW, Lee SS, Lee SJ, Um HD: Bcl-w is expressed in a majority of infiltrative gastric adenocarcinomas and suppresses the cancer cell death by blocking stress-activated protein kinase/c-Jun NH2-terminal kinase activation. Cancer Res 2003, 63(5):1093-1100.

34. Bae IH, Park MJ, Yoon SH, Kang SW, Lee SS, Choi KM, Um HD: Bcl-w promotes gastric cancer cell invasion by inducing matrix metalloproteinase-2 expression via phosphoinositide 3-kinase, Akt, and Sp1. Cancer Res 2006, 66(10):4991-4995.

35. Guo WJ, Wang AY, Gao C: Apoptosis and expression of apoptosis-related proteins $\mathrm{BCl}-2, \mathrm{BCl}-\mathrm{xL}$ and Bcl-w in human colon adenocarcinoma. World Chin J Degestology 2009, 17(25):2589-2594.

36. Sun XF, Sun ZY, Pan B, Li L, Shen W: Alteration in methylation pattern of oncogene Akt1 promoter region in bladder cancer. Mol Biol Rep 2012, 39(5):5631-5636.

37. Askham JM, Platt F, Chambers PA, Snowden H, Taylor CF, Knowles MA: AKT1 mutations in bladder cancer: identification of a novel oncogenic mutation that can co-operate with E17K. Oncogene 2010, 29(1):150-155.

38. Crawford M, Batte K, Yu L, Wu X, Nuovo GJ, Marsh CB, Otterson GA, Nana-Sinkam SP: microRNA 133B targets prosurvival molecules MCL-1 and BCL2L2 in lung cancer. Biochem Biophys Res Commun 2009, 388(3):483-489.

39. Wei Y, Hegarty JP, Berg A, Chen X, West G, Kelly AA, Wang Y, Poritz LS, Koltun WA, Lin Z: NKX2-3 transcriptional regulation of endothelin-1 and VEGF signaling in human intestinal microvascular endothelial cells. PLOS One 2011, 6(5):e20454.

40. Shen L, Li J, Xu L, Ma J, Li H, Xiao X, Zhao J, Fang L: miR-497 induces apoptosis of breast cancer cells by targeting Bcl-w. Exp Ther Med 2012, 3(3):475-480.

doi:10.1186/s12935-014-0070-3

Cite this article as: Chen et al:: MiR-133b regulates bladder cancer cell proliferation and apoptosis by targeting Bcl-w and Akt1. Cancer Cell International 2014 4:70.

\section{Submit your next manuscript to BioMed Central and take full advantage of:}

- Convenient online submission

- Thorough peer review

- No space constraints or color figure charges

- Immediate publication on acceptance

- Inclusion in PubMed, CAS, Scopus and Google Scholar

- Research which is freely available for redistribution 